\title{
Giant scalp arteriovenous malformation
}

\author{
Paulo Valdeci Worm ${ }^{1}$, Leonardo Gilmone Ruschel ${ }^{2 *}$, Marcelo Rosa Roxo ${ }^{3}$, Rafael Camelo ${ }^{3}$ \\ ${ }^{1}$ Neurosurgeon at Hospital São José, Santa Casa de Misericórdia de Porto Alegre, Porto Alegre, RS, Brazil \\ ${ }^{2}$ Resident of the Neurosurgery Program at Instituto de Neurologia de Curitiba (INC), Curitiba, PR, Brazil \\ ${ }^{3}$ Neurosurgery Resident, Hospital São José, Santa Casa de Misericórdia de Porto Alegre, Porto Alegre, RS, Brazil
}

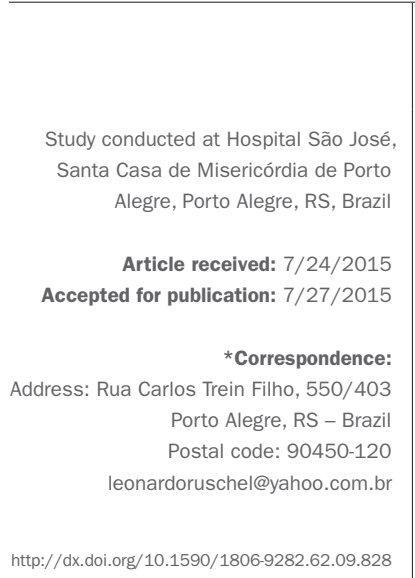

http://dx.doi.org/10.1590/1806-9282.62.09.828

\section{SUMMARY}

Arteriovenous malformations (AVMs) of the scalp are rare lesions. The clinical picture presents with complaints of increased scalp, scalp disfigurement, pain and neurological symptoms. Its origin can be congenital or traumatic. We present a case of giant scalp AVMs and its management, followed by a brief literature review on the subject. The diagnosis of scalp AVMs is based on physical examination and confirmed by internal and external carotid angiography or computed tomographic angiography (CTA). Surgical excision is especially effective in scalp AVMs, and is the most frequently used treatment modality.

Keywords: scalp, arteriovenous malformations, vascular diseases.

\section{INTRODUCTION}

Extracranial scalp arteriovenous malformations (AVMs) are relatively rare, accounting for only $8.1 \%$ of cases of AVMs. ${ }^{1}$ They are vascular aberrations that develop during the fetal period and result from failure of embryonic vasculature to differentiate into arteries and veins. ${ }^{2}$ Although controversy exists regarding the cause of these lesions, it is generally accepted that they may be either congenital or traumatic in origin. ${ }^{3}$

The clinical picture is characterized by increased scalp, scalp deformation, pulsatile mass, headache, tinnitus, convulsion, bleeding and dizziness, but it can often be asymptomatic. Diagnosis of AVMs is based on physical examination and confirmed by internal and external carotid angiography, or computed tomographic angiography (CTA). ${ }^{4}$ Treatment options include endovascular occlusion, direct percutaneous injection of sclerosing agents and, in selected cases, surgical resection. ${ }^{5}$

We present a case of scalp AVM and its management at our institution. We provide below a brief literature review and some commentaries regarding the clinical and radiological features of this rare entity.

\section{Case report}

We present the case of a 33-year-old male with a complaint of a pulsatile and increasingly bigger mass within the left temporo-occipital region of scalp for 3 years. There was no previous trauma. We identified an area of focal thickening of the scalp, above the lateral and occipital skull surfaces, soft and pulsatile on palpation. There was no audible bruit or any abnormalities on neurologic examination. The CTA demonstrated a lesion of vascular nature, presumably an arteriovenous malformation beneath the scalp. There was a nidus fed by branches from ipsilateral superficial temporal and occipital arteries (Figure 1). There was no communication with the intracranial circulation. The treatment of choice was surgical, with ligation of the feeder branches without scarifying parent vessels, with total excision of the malformation. Scalp irrigation was preserved (Figure 2). Postoperative period was uneventful, and postoperative CTA showed no significant and/or pathologic vessels left (Figure 3).

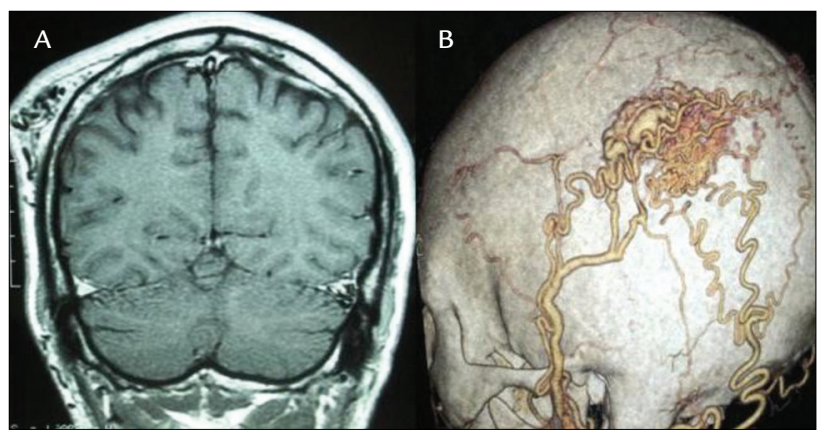

FIGURE 1 A. Coronal T1-W MRI showing the scalp AVM on the left parieto-occipital region. B. Markedly dilated superficial temporal and occipital arteries supplied the nidus; a draining vein can also be seen. 


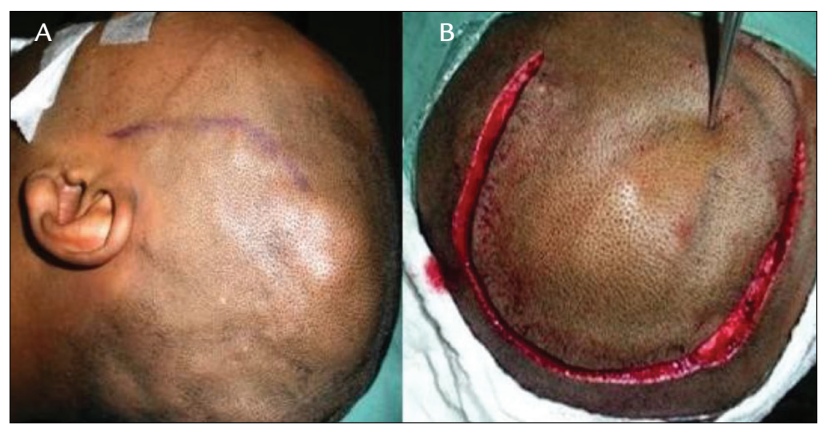

FIGURE 2 A. Soft thickened scalp can be seen above the left temporal and occipital skull surfaces, corresponding to the scalp AVM. B. A horseshoe incision was made with a view to preserving scalp irrigation, critical to the success of the surgery.

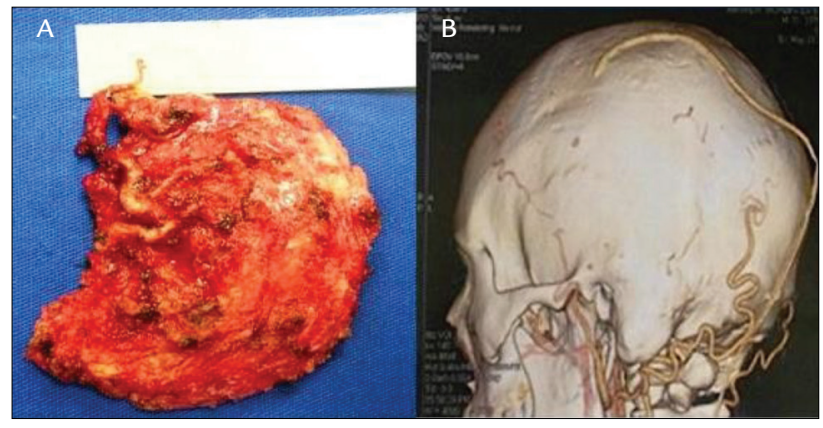

FIGURE 3 A. The scalp AVM shown after en bloc resection.

$B$. Postoperative CT showing no significant and/or pathologic vessels relative to the AVM.

\section{Discussion}

AVMs of the scalp are abnormal fistulous connection between the feeding arteries and draining veins, without an intervening capillary bed within the subcutaneous layer. Their rarity and unpredictable behavior render systematic studies, assessment of prognosis, and treatment controversies. ${ }^{6}$ Different names have been used to describe these lesions, and the most common are cirsoid aneurysm, plexiform angioma, scalp arteriovenous fistula, arteriovenous aneurysm and arteriovenous malformation. ${ }^{7}$

Almost all patients present with a scalp swelling that has gradually increased in size from birth or after head trauma. Rapid increases in size have been reported to occur at puberty, during menstruation and during pregnancy. Their clinical signs are associated with the size of AVMs. Associated symptoms and signs include pain, throbbing headaches and bruit, ${ }^{3,8,9}$ hemorrhage, ${ }^{8,10}$ seizures and psychomotor retardation. ${ }^{11}$ Large lesions have also been asso- ciated with scalp necrosis. ${ }^{8}$ AVMs cause direct shunting of high-volume arterial blood through low-resistance arteriovenous fistulae, often resulting in venous hypertension, hypoperfusion of vessels and tissue downstream, and reduced cerebral perfusion, known as the steal phenomenon. ${ }^{12}$ About 10 to $20 \%$ of scalp AVMs develop following penetrating or non-penetrating trauma to the scalp. ${ }^{3,13}$

Total excision of a scalp AVM requires comprehensive knowledge of the feeding arteries, draining veins and nidus. Catheter angiography has been the gold standard for diagnosis ${ }^{14}$ but CTA can also provide a very high imaging resolution and the observation of related bony structures, which may be important for surgical planning, as in the case of our patient. ${ }^{4}$

Treatment of scalp AVMs allows many possibilities and individualization is key. Surgical excision is especially effective in selective cases, when endovascular treatment is difficult or not feasible. ${ }^{3,5,15}$ Moreover, successful endovascular treatment of scalp AVMs has been reported, but has often been found to be insufficient for those with more extensive fistulae or with other complicating components. ${ }^{16}$

In relation to surgical treatment, common complications consist of hemorrhage, necrosis of the scalp, and sepsis caused by wound infection. ${ }^{3,17}$ Hemorrhage may be prevented with preoperative embolization, clamping, and suturing of feeding vessels. Several authors recommend preoperative endovascular treatment to reduce blood supply of large lesions, as to facilitate surgery. ${ }^{18,19}$

\section{Resumo}

Malformação arteriovenosa gigante de escalpo

Malformações arteriovenosas (MAV) do couro cabeludo são lesões raras. O quadro clínico apresenta-se com queixas de aumento do couro cabeludo, desfiguração do couro cabeludo, dor e sintomas neurológicos. A origem pode ser congênita ou traumática. Apresentamos um caso de MAV gigante de couro cabeludo e o tratamento adotado, seguindo-se uma breve revisão da literatura. O diagnóstico das MAV de couro cabeludo baseia-se no exame físico e é confirmado pela angiografia carótida interna e externa ou angiografia por tomografia computadorizada. A excisão cirúrgica é especialmente eficaz em MAV de couro cabeludo e é a modalidade de tratamento mais frequentemente utilizada.

Palavras-chave: couro cabeludo, malformações arteriovenosas, doenças vasculares. 


\section{References}

1. Huber P. Krayenbühl/Ya冈argil Cerebral angiography. 2. ed. New York: Thieme; 1982.

2. Schultz RC, Hermosillo CX. Congenital arteriovenous malformation of the face and scalp. Plast Reconstr Surg. 1980; 65(4):496-501.

3. Fisher-Jeffes ND, Domingo Z, Madden M, de Villiers JC. Arteriovenous malformations of the scalp. Neurosurgery. 1995; 36(4):656-60.

4. Teksam M, McKinney A, Truwit CL. Multi-slice CT angiography in evaluation of extracranial-intracranial bypass. Eur J Radiol. 2004; 52(3):217-20.

5. Barnwell SL, Halbach VV, Dowd CF, Higashida RT, Hieshima GB. Endovascular treatment of scalp arteriovenous fistulas associated with a large varix. Radiology. 1989; 173(2):533-9.

6. Kohout MP, Hansen M, Pribaz JJ, Mulliken JB. Arteriovenous malformations of the head and neck: natural history and management. Plast Reconstr Surg. 1998; 102(3):643-54.

7. Khodadad G. Arteriovenous malformations of the scalp. Ann Surg. 1973; 177(1):79-85.

8. Nagasaka S, Fukushima T, Goto K, Ohjimi H, Iwabuchi S, Maehara F. Treatment of scalp arteriovenous malformation. Neurosurgery. 1996; 38(4):671-7.

9. Dandy WE. Arteriovenous aneurysms of the scalp and face. Arch Surg. 1946; 52:1-32.

10. Kuroki K, Taguchi H, Sumida M, Eguchi K, Saitoh Y. [A case of hemorrhagic non traumatic arteriovenous fistula of the scalp]. No Shinkei Geka. 1999; 27(9):851-3.
11. Mohanty S, Rao CJ. A large cirsoid aneurysm of the scalp associated with epilepsy. J Neurol Neurosurg Psychiatry. 1976; 39(9):835-6.

12. Mast H, Mohr JP, Osipov A, Pile-Spellman J, Marshall RS, Lazar RM, et al. 'Steal' is an unestablished mechanism for the clinical presentation of cerebral arteriovenous malformations. Stroke. 1995; 26(7):1215-20.

13. Matsushige T, Kiya K, Satoh H, Mizoue T, Kagawa K, Araki H. Arteriovenous malformation of the scalp: case report and review of the literature. Surg Neurol. 2004; 62(3):253-9.

14. Wilkinson HA. Recurrence of vascular malformation of the scalp 18 years following excision. Case report. J Neurosurg. 1971; 34(3):435-7.

15. Massimi L, De Bonis P, Esposito G, Novegno F, Pettorini B, Tamburrini G, et al. Vertex scalp mass as presenting sign of a complex intracranial vascular malformation. J Neurosurg Pediatr. 2009; 3(4):307-10.

16. Lanzino G, Passacantilli E, Lemole GM Jr., McDougall C, Spetzler RF. Scalp arteriovenous malformation draining into the superior sagittal sinus associated with an intracranial arteriovenous malformation: just a coincidence? Case report. Neurosurgery. 2003; 52(2):440-3.

17. Muthukumar N, Rajagopal V, Manoharan AV, Durairaj N. Surgical management of cirsoid aneurysms. Acta Neurochir (Wien). 2002; 144(4):349-56.

18. Komiyama M, Nishikawa M, Kitano S, Sakamoto H, Imai K, Tsujiguchi K, et al. Non-traumatic arteriovenous fistulas of the scalp treated by a combination of embolization and surgical removal. Neurol Med Chir (Tokyo) 1996; 36(3):162-5.

19. Tanaka T, Hasegawa Y, Kanki T, Abe T. [Combination of intravascular surgery and surgical operation for occipital subcutaneous arteriovenous fistula in a patient with neurofibromatosis type I]. No Shinkei Geka. 2002; 30(3):309-13 